\title{
Tumor-associated antigens and development of immunotherapeutics strategies
}

\author{
R. G. Kyyamova, V. V. Filonenko \\ Institute of Molecular Biology and Genetics National Academy of Sciences of Ukraine \\ 150 Zabolotnoho st., Kyiv 03143, Ukraine \\ E. mail: kyyamova@imbg.org.ua; filonenko@imbg.org.ua
}

\begin{abstract}
The tumor-associated antigens, up-to-date methods for their identification and immunotherapeutics strategies for cancer treatment have been reviewed. The main attention has been focused on the antigens identified by SEREX (Serological identification of antigens by recombinant expression cloning) methodology and the categories of tumor-associated antigens (i. e. identified by SEREX appraach) have been listed. The main immunotherapeutic approaches have been classified, the successes of active specific immunotherapy based on immunodominant peptides of tumor-associated antigens have been described.
\end{abstract}

Tumor-associated antigens and methods for their identification. The identification and molecular characterization of tumor antigens in the tumor-bearing host are the major tasks in the tumor immunology. An analysis of humoral and cellular immune responses against such antigens in cancer patients indicates for a long time that tumor-associated antigens (TAA) do exist and are recognized by patient's immune system. These antigens are the potential targets for the antigen specific cancer immunotherapy and cancer diagnostics.

The first useful antigens - alfa fetoprotein, a serum marker for hepatoma and germ cell tumors, and carcinoembryonic antigen (CEA), a serum marker for colon and other epithelial cancers were identified by the analysis of heteroimmune sera obtained from rabbits and other animals immunized with human cancer cells $[1,2]$. In the 1970s and 1980 s, the monoclonal antibody technology was exploited for the identification of molecules on tumor cells that could be used as diagnostic markers or as target structures for the immunotherapeutic approa-

(C) R. G. KYYAMOVA, Y. V. FILONENKO, 2005 ches with monoclonal antibodies. Some of these efforts yielded new therapeutic tools, such as the antiCD20 antibody «rituximab» which showed considerable activity and has been licensed for the treatment of B-cell lymphomas [3]. However, the approaches of active immunotherapy require the identification of target structures, immunogenic in the autologous tumor-bearing host. There are two different opinions regarding the methods for searching antigens for active immunotherapy.

First, numerous studies on experimental animals showed that the cellular, rather than the humoral, immune response was in charge of the rejection of transplanted tumors or allogenic (genetically different) tissues. With the exception of antibodies against the growth factor receptors on cancer cells, the administration of antibodies has little effect on the growth of solid tumors. Thus, a significant effort should be directed at identification of the antigens recognized by human T-lymphocytes $[4,5]$. On the other hand, it is now commonly accepted that immune recognition of tumors is a concerted action. Hence, high-titer circulating tumor-associated antibodies of the immunoglobulin $G$ (IgG) class may reflect a 
significant host-tumor interaction and identify such gene products, against which at least cognate $T$ helper cells and specific cytotoxic $\mathrm{T}$-cells should exist [6]. The present review describes the categories of TAA and methods for their identification are as well as some immunological strategies for cancer immunotherapy, based on molecular identification of TAA. The main attention is focused on the serological approach to search for TAA (SEREX), but T-celldefined tumor antigens and techniques for their identification are also considered.

Since T-cells play an essential role in tumor growth inhibition and cancer cells eradication, first of all some useful techniques have been developed to identify the cancer antigens capable of eliciting cellular immune response. The genetic approach represents the transfection of genomic DNA or cDNA libraries into the cells expressing the appropriate major histocompatibility complex (MHC) molecules, followed by the identification of the transfectants using cytokine release or lysis by human $\mathrm{T}$-cells (CTL - cytotoxic T-lymphocytes) with specific antitumor reactivity [7]. The biochemical technique offers the elution of peptides from tumor cells or from MHC removed from tumor cells surface and detection of fractions capable of stimulating antitumor T-cells after pulsing purified peptides onto antigen-presenting cells. The triple quadrapole mass spectrometric techniques have been used to sequence the minute quantities of peptides obtained [8].

Another method is an identification of tumor antigens by in vitro sensitization of $T$-cells against possible tumor antigens [9]. T-cells culture successfully sensitized in vitro against these antigens have been tested for their ability to recognize the intact tumor cells, and that provides strong evidence that these candidate proteins represent the tumor antigens [9].

The mechanism of eradication of cancer cells by T-lymphocytes involves both CD8 cytotoxic T-cells and CD4 T-helper cells that recognize antigens presented as small peptides by the MHC classes I and II. CD8 T-cells recognize peptides derived from intracellular cytoplasmic proteins, digested in proteasomes and presented via the endoplasmatic reticulum on the cell surface by class I MHC. In contrast, CD4 cells use a different intracellular pathway for engulfed extracellular proteins, digested to peptides in intracellular endosomes and presented on cell surface by class II MHC molecules. Since CD8
CTL can lyse tumor cells directly and destroy large tumor masses in vivo, several tumor antigens, presented by MHC I, have been defined using the tumorreactive CD8 T-cells. Clinical trials using the tumor antigens have evidenced some therapeutic effects inhibiting tumor growth. However, the overall immune response was too weak and transient to eradicate cancer cells in the majority of patients who were immunized. Though a growing body of evidences suggests that $\mathrm{CD} 4 \mathrm{~T}$-cells play a central role in initiating and maintaining immune responses against cancer $[10]$, the optimal vaccination might require the participation of both CD4 and CD8 T-cells to generate a strong and long-lasting antitumor immunity. Although MHC II restricted tumor antigens are clearly important, some problems exist for their identification due to special requirements for MHC II antigen processing and presentation.

The ability of antigen-presenting cells (APC) to endocytose proteins and to present peptides by $\mathrm{MHC}$ II has been utilized to identify antigens recognized by CD4 T-cells, although so far few antigens have been identified using this approach [11]. A genetic targeting expression (GTE) approach has been developed that allows the screening of cDNA library fused to genes encoding invariant chain (Ii) sequences for identification of MHC II restricted antigens, designed to guide the transfected proteins into the class II presentation pathway [12].

Thus, during the last few years, effective strategies of identification of TAA recognized by specific $T$-cells have resulted in the characterization of various antigens, such as the melanoma differentiation antigens, CEA, epithelial cell adhesion molecule, HER$2 \backslash$ new, Wilms tumor protein, proteinase 3, NY-ESO1, antigens of MAGE, BAGE, GAGE, SSX-families, etc. as described by Renkvist et al. [13]. The authors have summarized more than $60 \mathrm{MHC}$ class 1 related TAA, recently identified [13]. A completed list of $T$-cell epitopes can be found in the peptide database of T-cell defined tumor antigens (http://www.cancerimmunity.org/peptidedatabase/Tcellepitopes.htm).

SEREX approach and categories of tumor-associated antigens. Unfortunately, all the techniques listened above are technically challenging because they require the establishment of autologous CTL lines and tumor cell lines from the same patient, a task not achievable for most epithelial tumor types [14]. An alternative technique that circumvents these limitation has been developed by Pfeundschuh and 
his colleagues [15]. They call their approach SEREX for «serological identification of antigens by recombinant expression cloning». SEREX has been designed to isolate tumor antigens that elicit high-titer IgG response in human hosts. In their initial application of this method, Pfeundschuh and his colleagues identified MAGE-A1 and tyrosinase, two antigens originally cloned as CTL targets, indicating that SEREX can detect tumor antigens that elicit the CTL-mediated immune response [15].

SEREX allows a systematic and unbiased search for antibody responses and direct molecular definition of immunogenic tumour proteins, based on their reactivity with autologous patient serum. In the $\mathrm{SE}$ REX approach, a cDNA expression library is constructed from a fresh tumour specimen, and cloned into $\lambda$ phage expression vectors. The resulting recombinant phages are then used to infect Escherichia coli. Recombinant proteins expressed during the lytic infection of the bacteria are transferred onto nitrocellulose membranes, which are incubated with diluted $(1: 100-1: 1000)$ and depleted from anti $E$. coli and anti $\lambda$ phage antibodies serum from the autologous patient. Clones reactive with high-titre antibodies are identified using an enzyme-conjugated secondary antibody specific for human IgG. Positive clones are subcloned to monoclonality, and the nucleotide sequence of the cDNA insert is determined. cDNA sequence analysis via database searching is performed to define whether the CDNA inserts are derived from novel genes or cancer-associated known genes. The domains and/or motifs for putative function and cellular localisation of the antigens can be also identified. The SEREX approach characterized by several features is reviewed by Sahin et al. [16]. The main of them is using fresh tumor specimens that circumvent in vitro the artifacts associated with the short- and long-term tumor cell culture. This eliminates the need of establishing tumor and CTL cell lines.

However, the data accumulated over recent years evidence that antigen repertoire detectable by the conventional SEREX approach to be limited [6]. This might be in part attributed to the fact that the potential antigens modificated posttranslationally remain undetected in bacterial expression systems. The posttranslational modifications play an important role in the proper function of many proteins and also affect their immunogenicity. To overcome some of the inherent problems with the conventional SEREX sys- tem, «recombinant antigen expression on yeast surface» (RAYS) has been proposed recently to establish a eukaryotic expression system in yeast. Yeasts have the advantage that recombinant proteins can be expressed on the cell surface in a more naturally folded, partially glycosylated manner [17]. A number of other modifications of the original method have been proposed recently. Subtractive approaches allow enrichment of the cDNA library for tumor specific transcripts [18]. cDNA libraries may also be prepared from sources of specific interest, such as amplified chromosomal regions obtained by microdissection [19]. Another alternative cloning strategy for TAA with a possibility of high throughput analysis of patient sera and tumor libraries has been projected newly. The pJuFo phage surface display, allowing display of recombinant tumor proteins on the surface of M13 filamentous phage, has been explored for cloning TAA in prostate cancer [20].

In 1995 the SEREX program was initiated under supervision of Dr L. Old, the head of Ludwig Institute for Cancer Research (LICR). The SEREX collaborative group involve the investigators from the University of Saarland (Hamburg, Germany), Ludwig Institute Branches in New York, San Diego (USA), Melbourne (Australia), and London (UK, University College); Aichi Cancer Center (Naoya, Japan), Krankenhaus Nordwest (Frankfurt, Germany), Mie University School of Medicine (Mie, Japan), Moscow State University (Moscow, Russia), and the Institute of Molecular Biology and Genetics (Kyiv, Ukraine).

During the last few years, SEREX has been applied to a wide range of tumor types, including melanoma, renal cancer, astrocytoma, Hodgkin's disease [15], oesophageal cancer [21], gastric cancer [22], colon cancer [23], lung cancer [24], breast cancer [25], prostate cancer [26], leukaemia [27] and thyroid cancer [28]. For the systematic documentation and archiving of sequence data and immunological characteristics of identified antigens, the electronic SEREX database, established by the LICR,

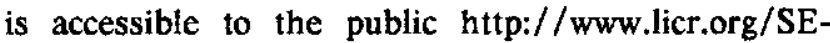
REX.html. To date more than 2,000 antigens have been listed in the SEREX database [6]. According to their expression patterns in normal and malignant tissues, several categories of tumor antigens can be distinguished. The table 1 lists the categories of the tumor antigens identified.

Cancer-testis (CT) antigens are a fascinating category of tumor antigens with the expression res- 
Table 1

Categories of human cancer antigens

\begin{tabular}{|c|c|c|}
\hline Catezories & Examples & References \\
\hline \multirow[t]{4}{*}{ Cancer-Testis antigens } & NY-ESO-1 & [21] \\
\hline & MAGE & [29] \\
\hline & BAGE & {$[30]$} \\
\hline & GAGE & [31] \\
\hline \multirow[t]{2}{*}{ Differentiation antigens } & Melan AIMART-1 & {$[34,35]$} \\
\hline & Tyrosinase & {$[36]$} \\
\hline \multirow[t]{2}{*}{ Amplified loverexpressed antigens } & eLF- $4 \gamma$ & [19] \\
\hline & HER2\new & [44] \\
\hline Mutated antigens & $\mathrm{p} 53$ & [23] \\
\hline Splice variants & Restin & {$[15]$} \\
\hline Virus encoded antigens & $\begin{array}{c}\text { Human pappiloma } \\
\text { virus }\end{array}$ & [46] \\
\hline Cancer-related autoantigens & HOM-MEL-2.4 & {$[7]$} \\
\hline
\end{tabular}

tricted to male germ cells in the testis, in some cases in ovary and in throphoblast, but not in adult somatic tissues. In malignancy, the gene regulation is disrupted, resulting in CT antigen expression in tumors of various type. Many of the genes coding for these antigens are mapped to chromosome $X$ and exist as multimember families. The representatives of this category, MAGE [29], BAGE [30], and GAGE [31], were initially identified as targets for the cytotoxic T-cells. The HOM-Mel-40 antigen (gene SSX-2), detected in the melanoma library, is the first CT antigen identified by SEREX [32]. The SEREX analysis of esophageal cancer resulted in the identification of the NY-ESO-1 gene with restricted expression in testis and various cancers [21]. The success of SSX and NY-ESO-1 cloning prompted a series of the SEREX studies of various tumor types, and that led to the identification of additional CT antigens, i. e. CT7/MAGE-C1, SCP-1, HOM-TES85, Ctage-1, OY-TES-1, and most recently CAGE as reviewed by Scanlan et al. [14]. To date approximately $20 \mathrm{CT}$ antigens families have been identified and the list of CT antigens has been greatly expanded through serological expression cloning (SEREX). Recently, several new techniques have been used for CT antigen discovery based on restricted pattern of the CT gene expression. Representational difference analysis (RDA) led to the identification of LAGE1, CT10, SAGE, the differential display - CTp11. The oligonucleotide array analysis allowed to discover
MMA-1A gene, and through bioinformatic approach some CT antigens were identified - BRDT (CT9), fertilin $\beta$ (CT15), CT16 and CT17 [14]. With the exception of SCP-1, OY-TES-1, and CT15 (fertilin $\beta$ ), the biological function of the most CT antigens is not known. CT antigens are characterized by heterogeneous protein expression in cancer, likely correlation with tumor progression, immunogenicity in cancer patients, and induction of expression by hypomethylation and histone acetylation. A demethylation state in cancer (whatever its cause) may induce the gametogenic program and result in the activation of silent CT genes. Alternatively, the demethylation may be an intrinsic part of the gametogenic program, and therefore a consequence, not a cause, of switching on the gametogenic program and $\mathrm{CT}$ genes in cancer [33]. Cancer-testis antigens are ideal targets for cancer immunotherapy.

Differentiation antigens are expressed in tumor in a lineage-associated manner, but found also in normal cells of the same origin. Melan A/MART-1 [34, 35], tyrosinase [36], gp100 [37, 38], gp75/TRP-1 [39] antigens have been found in malignant melanomas, a particularly rich source of differentiated antigens, the expression of which is limited to melanomas as well as melanocytes, the cells of this tumor origin. The next examples are glial fibrillary acidic protein (GFAP), which is antigenic in malignant glioma, but also expressed in brain cells [40], and recently found NY-BR-1 expressed in 70-80\% of breast cancer, $25 \%$ of prostate cancer as well as in normal breast, prostate and testis tissues [41].

Amplified/overexpressed antigens coded by amplified or overexpressed genes have also been identified through SEREX. Among them are HOM-RCC-3.1.3, new carbonic anhydrase identified in renal cancer [42], Bax inhibitor protein 1-in glioma [40], eLF- $4 y$ - in squamous cell lung cancer [19], galectin 9 - in Hodgkin's disease [43], indicating that antigen overexpression can lead to immunogenicity, as in the case of HER2/new [44].

Mutated antigens have rarely been demonstrated using the serological approach, mutated p 53 being the only example [23]. As reviewed by Rosenberg [4], a variety of mutated antigens, MUM-1, CDK4, caspase$8, \beta$-catenin, and their mutated epitopes have been identified with autologous $\mathrm{T}$-cells.

Splice variants antigens have been detected by serological approach, for example, the Hodgkin's disease-associated variant of restin [15] and gastric 
cancer associated splice variant of $\mathrm{TACCl}$ antigen [45].

Virus encoded antigens are expressed in different malignancies in humans. Many of viruses associated with oncogenesis can present proteins on the induced cancer antigens that can serve as the targets for immune attack. These viral antigens can be also used as targets for preventive or therapeutic vaccination. However, the induction of neutralizing antibodies against envelope viral proteins can prevent the antigen-specific immune response in cancer patients immunized with the recombinant viruses vaccines [46].

Cancer-related autoantigens are expressed ubiquitously and at similar levels in both healthy and malignant tissues. Cancer-related autoantigens, in contrast to non-cancer-related antigens, that elicit antibody response only in cancer patients, and not in healthy individuals that elicit antibody response with similar frequencies in both healthy individuals and cancer patients. This might result from tumor-associated post-translational modifications or changes in antigen processing and/or presentation in tumor cells. An example is HOM-MEL-2.4 that represents the CCAAT enhancer binding protein [7].

Thus, systematic application of antibody-based (SEREX) and CTL-based methods has led to the definition of growing number of TAA. The multitude of tumor-specific antigens identified by the SEREX approach demonstrates that there is ample immune recognition of human tumors by the autologous host's immune system. Together with the identification of T-lymphocyte epitopes, a picture of immunological profile of cancer is emerging. Knowledge of cancer immunome (i. e. the sum of all the proteins expressed by tumor-bearing autologous host) provides a new basis for understanding tumor biology and for development of new diagnostic and therapeutic strategies for cancer. Besides their roie as targets for cancer vaccination, the identified antigens may be useful as new molecular markers of malignant diseases. The value of each of these markers or a combination of them for diagnostic or prognostic evaluation of cancer patients has to be determined by correlation between markers expression and clinical data. Furthermore, the immune system is a sensitive biodetector, which may determine structural and regulative alterations and may therefore point to gene products of significance for neoplastic transformation or tumour progression [47].
Development of immunotherapeutic strategies. The first clear indication that immunological manipulation could cause the regression of established invasive human cancers came from the studies on administration of interleukin-2 (IL-2) to patients with metastasis kidney cancer or melanoma [48]. The discovery of tumor antigens and the identification of their immunodominant epitopes have shifted emphasis to the utilization of these antigens to mediate the destruction of growing cancers in humans. Attempts are in progress to develop immunotherapies based on the specific stimulation of immune reactions against defined tumor antigens rather than on the nonspecific stimulation of the immune system that is characteristic of the prior approaches.

Specific as well as non-specific immunotherapies fall into either adoptive or active immunotherapy (tabl. 2). Early studies on non-specific adoptive immunotherapy of tumor-bearing patients involved the transfer of limphokine-activated killer (LAK) cells that recognize and lyse cancer cells in vitro [49]. For these purposes TIL (tumor infiltrated lymphocytes from respective tumors) could be expanded to $10^{10}-$ $10^{11}$ cells and then adoptively transferred along with IL-2 into melanoma patients [50]. Non-specific active immunotherapy used either autologous or allogenic whole cancer cells or cancer cells extracts for immunization of cancer patients. As reviewed by Rosenberg [46], the vaccines based on cancer cells were derived from: whole cancer cells (both autologous and allogenic preparation), gene-modified cancer cells (genes encoding cytokines or co-stimulatory molecules) or cancer cell extracts (lysates, membranes and heatshock proteins) and cancer cells fused to APC. Measurable specific immune responses were rarely detected following this approach, and the efficacy of immunization was reflected only by clinical development [51].

The identification of human cancer antigens has opened a new era of specific cancer immunotherapy. To date specific cancer immunotherapy (tabl. 2) based either on the adoptive transfer of the in vitro generated lymphocytes with high level of specific reactivity against tumor antigens (passive or adoptive immunotherapy) or on immunization against specific cancer antigens (active immunotherapy), represents attractive approaches. Cancer antigens has facilitated the in vitro generation of anti-tumor T-cells which can be expanded and used for specific adoptive immunotherapy [52]. The genetic modification of these 
Table 2

Immunotherapeutic strategies

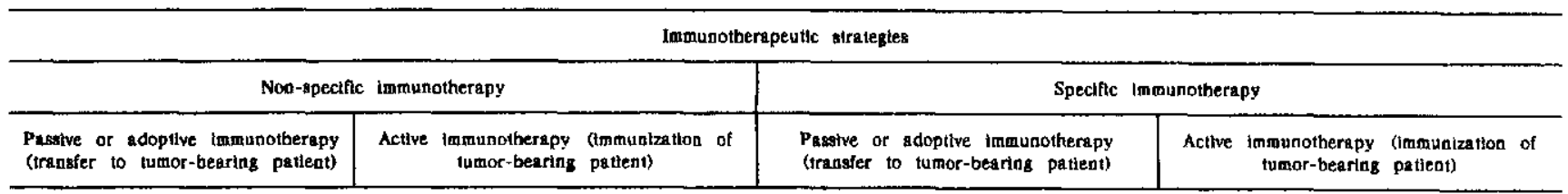

LAK-limphokine-activated killer cells, TIL-tumor infiltrated lymphosytes
Whole cancer cells, gene modified cancer celis (genes encoding cytokines or co-stimulatory molecules), cancer cell extracts (lysates, membranes and heatshock proteins), cancer cells fused with APC
T-cells, generated in vitro against specific cancer antigens, immunodominant peptides or utilizing tumor antigens pulsed on to APC and the same $\mathbf{T}$-cells genetically modified (by inserting genes encoding anti-tumor or chemokine receptors and anti-tumor cy tokines), specific monoclonal antibody
Purified cancer antigens (natural or recombinant), synthetic peptides alone or pulsed on to APC, knaked DNA", recombinant viruses (adenovirus, vaccinia or avipox), recombinant bacteria (Bacille Calmete-Guerin and Listeria) lymphocytes to improve their anti-tumor efficacy (for instance, by inserting genes, encoding anti-tumor or chemokine receptors, or genes, encoding anti-tumor cytokines) is under active investigation [53]. In vitro sensitization techniques, using repeated in vitro stimulation against immunodominant peptides or utilizing tumor antigens pulsed onto professional APC, have resulted in the in vitro generation of $\mathrm{T}$-cells with extremely high antitumor activity. Clinical protocols utilizing the specific adoptive transfer of these in vitro sensitized cells, are in progress as well [24]. Specific active immunotherapy suggests using purified cancer antigens (natural or recombinant), synthetic peptides alone or pulsed onto APC, «naked» DNA (for example, plasmids), recombinant viruses (adenovirus, vaccinia or avipox) and recombinant bacteria (Bacille Calmete-Guerin and Listeria) as cancer vaccine, and represents the most perspective and promising approach. The advantage of antigen-specific vaccination is a possibility of monitoring specific vaccine-induced immune responses that is for the identification of mechanisms mediating tumor regression in vivo [46]. The efficacy of cancer vaccines is affected by the immunogenicity of antigens, the route of immunizations and tumor features making them susceptible to immunologic recognition [51]. The main goal of cancer vaccination is the induction of an effective specific response against tumor cells which spares the cells of normal tissues. With respect to specificity, several classes of antigens may be suitable targets; in addition to the $\mathrm{CT}$ antigens, these include differentiation antigens, tumor associated overexpressed gene products, mutated gene product and tumorspecific splice variants [6].
A number of vaccines based on tumor associated antigens, i. e. SEREX-defined antigens, have been developed for the needs of specific active immunotherapy. Several steps of the analysis are required before SEREX-defined antigens become potential targets for the active immunotherapy trials in cancer patients as reviewed by Jager et al. [54].

As the first step, a careful expression analysis of each antigen has to be performed by comparing the cDNA sequence with EST databases. The antigens with restricted expression according to the database analysis are being tested by RT-PCR using a panel of normal and tumor tissues cDNAs to confirm the restricted mRNA expression pattern.

The antigens that show a tumor/tissue-restricted expression pattern, undergo a serological analysis to define the frequency of humoral immune responses in sera derived from cancer patients and normal individuals. A limited number of sera can be tested using the phage-plaque assay; for large-scale serology, the recombinant protein has to be produced and tested in Western blot assays or ELISA.

The antigens with tumor/tissue-specific expression and detectable humoral immune responses in tumor patients have to be analyzed for T-cell recognition. An approach called the reverse immunology approach allows testing the entire protein sequence of the respective antigen for potential $\mathrm{MHC}$ I binding sequences (see CancerImmunomeDB, SYFPEITHI database of MHC ligands and peptide motifs at http://www.bmi-heidelberg.com/syfpeithi/). Peptidespecific CTL can be generated upon in vitro stimulation, and recognition of target cells expressing the antigenic protein will be documented. The tumor 
antigens that represent the target antigens for CD8 T-cells can be used to immunize the patients with antigen-positive tumors.

The following list summarizes the steps of analyzing SEREX-defined antigens as potential targets for CD8 T-cells: SEREX analysis - Database analysis - Expression analysis - Serology-MHC-motif search for epitopes - ELISPOT assays (T-cell reactivity) - Immunotherapy trial [54].

Among a number of cancer vaccine trials performed with tumor antigens, «naked» DNA, APC, tumor cells, cytokines, co-stimulatory molecules and so on, the immunization strategy with immunodominant peptides derived from tumor antigens is the most attractive. Promising immunologic and clinical results were observed after vaccination with the peptides derived from the CT antigens MAGE-3 [55] and NY-ESO-1 [56]. The detectable peptide-specific CD8 $T$-cell responses were associated with the regression of metastatic lesions in single patients [55]. The objective tumor regression was observed in single patients under continued immunization with the peptide derived from melanocyte differentiation antigens MelanA/MART-1 [57] and tyrosinase [58]. The overexpressed antigens, such as HER-2\new, wildtype 53 and viral antigens, for example, the proteins of Human pappiloma viruses may also represent useful targets for therapeutic and/or preventive immunologic intervention [51]. The immunization strategies with MHC II restricted peptides are increasingly studied in vaccine trials $[59,60]$. The antigenic peptides derived from different cancer antigens (used either alone or combined with cytokines i. e., IL-2, IL-12, GM-CSF or adjuvants i. e., incomplete Freund's adjuvant, QS21) lead to the induction of strong specific CD T-cell responses [51]. The immunogenicity of peptide epitopes may be signficanty increased in vitro by modifying specific amino acid anchoring residues (e. g., exchange of cysteine with valine or alanine) [61]. Enhanced immunologic effects were observed in clinical studies using dendrite cells loaded with the peptide derived from cancer antigens, i. e. MAGE-3, MelanA \MART-1, that were related with disease stabilization and regression of metastasis melanoma lesions in single patients [62].

The local immune reactions, i. e., DTH reactions, inflammatory enlargement of lymph nodes, were observed after the antigen administration depending on the route of immunization: intradermal, intralymphatic or subcutaneous. The overall goal of clinical vaccine trials is the induction of $\mathrm{CD} 8$ and/or CD4 $T$-cell responses against the defined cancer antigens. Currently, the ELISPOT assay and structure-based peptide-MHC-tetramer assay measuring the magnitude of CD8 $T$-cell responses in the peripheral blood, in tumor-infiltrating lymphocytes, and in draining lymph nodes were established to be the most sensitive methods to determine the function and the quantity of the vaccine induced effector cells. In the function-based ELISPOT assay, antigen-specific cells are detected on the basis of proximal cytokine production [63]. The structure based peptide-MHCtetramer assay is the method of identifying antigenspecific T-cells on the basis of $\mathrm{T}$-cell receptor recognition by its ligand, the peptide-MHC complex [64]. Novel immunological tools that can be used not only to quantify the antigen-specific response, but also to analyze the phenotype and function of individual effector cells are described in the review of Yee and Greenberg [65].

In response to effective immunotherapy, the tumor cells may evolve the mechanisms that allow them to escape immune recognition. Such immunoselection can cause an outgrowth of the tumor cell population that has lost the expression of a given target antigen [66]. A significant form of the immune escape is an ability of tumor cells to evolve the mechanisms that impede the antigen processing and presentation, including the alteration or loss of the expression of MHC alleles, $\alpha_{2}$-microglobulin and transporter molecules associated with the antigen processing (TAP). Tumor cells can also secrete the immunosupressive cytokines such as transforming growth factor (TGF)$\beta$ and IL-10, which can inhibit the T-lymphocyte effector function [67]. Usage of polyvalent vaccines, specific for several tumor-associated antigens, or vaccination with antigens required by the tumor for maintenance of it's malignant phenotype (e. g. telomerase), can circumvent this form of the immune escape $[67,68]$. The information on the composite expression of different antigens in a given tumor is crucial for the design of polyvalent vaccine strategies. It is important to assess the number of patients that are suitable for a combined or sequential vaccination with two or more tumor antigens, because such a strategy could have the potential of reducing or even preventing the in vivo selection of antigen loss tumor cell variants $[67]$.

Hence, during last two decades the successes of immunotherapy resulted in the development of diverse 
modern immunotherapeutic strategies for cancer treatment. The identification of tumor-associated antigens has opened a new era of tumor immunology and unlimited possibilities for development of active specific immunotherapy. Novel immunotherapeutic approaches to cancer treatment and vaccines of new generation have been developed due to the successes in the field of molecular biology, cell immunology and genetic engineering. Modern methods of monitoring immune response make possible to investigate the molecular mechanisms of immune response during immunotherapeutic manipulations that allow to understand the origin of cancer and to improve the treatment of cancer diseases.

\section{Р. Г. Кіямова, В. В. Філоненхо}

Асоційовані 3 пухлиною антигени та розвиток імунотерапевтичних стратегій

\section{Резюме}

Зроблено охляд асоційованих з пухлиною антиzенів, методів їхної ідентифікації та існуючих на сьогоді імунотерапевтичних стратегій щодо лікування раку. Особлиеу уваху приділено антигенам, ідентифікованим 3 використанням методоrozï SEREX (сероловчіна ідентифікація антиеенів за допомогою рекомбінантно експресованих ктонів) та наведено катесоріі асоційованих з пухлиною антиеенів (у тому числі, ідентифікованих із застосуванням SEREX). Класифіковано головні імунотерапевтичні підходи та описано успіхи ахтивної специфінної імунотерапї̈ за допомогою імунодомінантних пептидів асоційованих з пухлиною антигенів.

Ключові слова: імунотерапія, антиген, рак.

\section{Р. Г. Киямова, В. В. Филоненко}

Ассоциированные с опухолью антитены и развитие иммунотерапеятических стратегий

Резюме

Сделан обзор ассочиированных с опухолью антигенов, методов их идентифихачии и существуюицх на сегодняиний день иммунотерапевтических стратегий для лечения рака. Основное внимание уделено антигенам, идентифищированньм с помоцыю методологии SEREX (серологическая идентифихачия антигенов с использованием рекомбинантно екпрессируемых клонов) и перечислень категории ассоциированных с опухолью антигенов (в том числе идентифицированных SEREX). Kлассифицированы основные иммунотерапевтические подходы $u$ описаны успехи актияной специфинеской им.мунотерапии $c$ помочью иммунодоминантньх пептидов ассочиированньх $c$ опухолью антигеное.

Ключевые слова: иммунотерапия, антихен, рак.

\section{REFERENCES}

1. Abelev G. I., Perova S. D., Khramkova N. I. Production of embryonal alphaglobulin by transplantable mouse hepatomas // Transplantation. - 1963. - 1.-P.174-180.
2. Gold P., Freeman S. $O$. Specific carcinoembryonic antigens of the human digestive system // J. Exp. Med.-1965.-122.P. 467-468.

3. Maloney D. G., Grillo-Lopez A. J., White C. A., Bodkin D., Schilder R. J., Neidhart J. A., Janakiraman $N$., Foon $K$. A., Liles T. M., Dallaire B. K., Wey K., Royston I., Davis T., Levy $R$. IDEC-C2B8 (Rituximab) anti-CD20 monoclonal antibody therapy in patient with relapsed low-grade non-Hodgkin's lymphoma // Blood. -1997.-90.-P. 2188-2195.

4. Rosenberg $S$. $A$. A new era for cancer immunotherapy based on the genes that encode cancer antigens // Immunity.1999.-10.-P. 281-287.

5. Boon T., Couli P. G., Van den Eynde B. Tumor antigens recognized by $T$ celis $/ /$ Immunol. Today, $-1997 .-18 .-$ P. 267-268.

6. Preuss K. D., Zwick C., Bormann C., Neumann F., Pfreundschuh $M$. Analysis of the $B$-cell repertoire against antigens expressed by human neoplasms // Immunol. Revs.-2002.188.-.P. 43-50.

7. Boon $T$. Tumor antigens recognized by cytolytic $T$ lymphocytes: present perspectives for specific immunotherapy $/ /$ Int. J. Cancer.-1993.-54.-P. 177-180.

8. Cox A. L., Skipper J., Chen, Y., Henderson R. A., Darrow T. $L$, Shabanowitz J., Engelhard $V . H$, Hunt $D$. F., Slingluff $C$. $L$. Identification of a peptide recognized by five melanomaspecific human cytotoxic $T$ cell lines // Science.-1994.264.-P. 716-719.

9. Parkhurst M. R., Fitzgerald E. B., Southwood S., Sette A., Rosenberg $S$. A., Kawakami $Y$. Identification of a shared HLAby A0201-restricted T-cell epitope from the melanoma antigen tyrosinase-related protein 2 (TRP2) // Cancer Res.1998. - 58. -P. 4895-4901.

10. Toes $R$. E., Ossendorp F, Offringa $R$., Melief $C, C D 4 T$ cells and their role in antitumer immune responses $/ / \mathrm{J}$. Exp. Med.-1999.-189.-P. 753-756.

11. Topalian S. L, Rivoltini L, Mancini M., Markus N. R., Robbins P. F., Kawakami Y., Rasenberg S. A. Human CD4t $T$ cells specifically recognize a shared melanoma-associated antigen encoded by the tyrosinase gene // Proc. Nat. Acad. Sci. USA.-1994.-91.-P. $9461-9465$

12. Wang $R$. F., Wang X., Atwood A. C., Topalian S. L, Rosenberg $S$. A. Cloning genes encoding MHC class 11restricted antigens: mutated CDC27 as a tumor antigen // Science.-1999.-284.-P. 1351-1354

13. Renkvist N., Castelli C., Robbins P. F., Parmiani G. A listing of human tumor antigens recognized by $\mathrm{T}$ cells // Cancer Immunol. Immunother.-2001.-50.-P. 3-15.

14. Scanlan $M$. J., Gure A. O., Jungbluth A. A., Old L. J., Chen $Y . T$. Cancer/testis antigens: an expanding family of targets for cancer immunotherapy // Immunol. Revs._2002.-188.P. 22-32.

15. Sahin U., Tureci O., Schmitt H., Cochlovius B., Johannes T., Schmits R., Stenner F., Luo G., Schobert I., Pfreundschuh $M$. Human neoplasms elicit multiple specific immune responses in the autologous host // Proc. Nat. Acad. Sci. USA.-1995.92.-P. 11810-11813.

16. Sahin U., Tureci $O$., Pfreundschuh $M$. Serological identification of human tumor antigens // Curr. Opin Immunol.1997. -9.-P. 709-716.

17. Boder $E$. T., Wittrup $K . D$. Yeast surface display for directed evolution of protein expression, affinity, and stability // Meth. Enzymol,-2000--328.-P. 430-444.

18. Tureci O., Sahin U., Zwick C., Koslowski M., Seitz G., Pfreundschuh $M$. Identification of panel a meiosis-specific 
protein as a member of the class of cancer/testis antigens // Proc. Nat. Acad. Sci. USA.-1998.-95.-P. 5211-5216.

19. Brass N., Heckel D., Sahin U., Pfreundschuh M., Sybrecht $G$. $W$., Meese $E$. Translation initiation factor elF-4gamma is encoded by an amplified gene and induces an immune response in squamous cell lung carcinoma // Hum. Mol. Genet.1997.-6.-P. 33-39.

20. Fossa A., Alsoe L., Crameri R., Funderud S., Gaudernack G., Smeland $E$. B. Serological cloning of cancer/testis antigens expressed in prostate cancer using CDNA phage surface display // Cancer Immunol. Immunother.-2004.-53.-P. 431-438.

21. Chen Y. T., Scanlan M. J., Sahin U., Tureci O., Gure A. O., Tsang S., Williamson B., Stockert E., Pfreundschuh M., Old $L$. $J$. A testicular antigen aberrantly expressed in human cancers detected by autologous antibody screening // Proc. Nat. Acad. Sci. USA.-I997.-94.-P. 1914-1918.

22. Line A., Stengrevics A., Slucka Z., Li G., Jankevics E., Rees R. C. Serological identification and expression analysis of gastric cancer-associated genes // Brito. J. Cancer.-2002.86. -P. 1824-1830.

23. Scanlan M. J., Chen Y. T., Williamson B., Gure A. O., Stockert E., Gordan J. D., Tureci O., Sahin U., Pfreundschuh $M$. Old $L$. $J$. Characterization of human colon cancer antigens recognized by autologous antbodies // Int. J. Cancer.1998.-76.-.P. 652-6.58.

24. Gure A. O., Altorki N. K, Stockert E., Scanlan M. J., Old L. $J$., Chen $Y . T$. Human lung cancer antigens recognized by autologous antibodtes: definition of a novel CDNA derived from the tumor suppressor gene locus on chromosome 3p21.3 // Cancer Res.-1998.-58.-P. 1034-1041.

25. Obata Y. T., Akahashi T., Tamaki H., Tominaga S., Murai $H$., Iwase T., Iwata H., Mizutani $M$., Chen $Y$. T., Old $L$ J., Miura $S$. Identification of cancer antigens in breast cancer by the SEREX expression cloning method // Breast Cancer.1999.-6.-P. 305-311.

26. Zhou Y., Toth M., Hamman M. S., Monahan S. J., Lodge P. A., Boynton A. L. Salgaller $M$. $L$ Serological cloning of PARIS-1: a new TBC domain-containing, immunogenic tumor antigen from a prostate cancer cell line // Biochem. and Biophys. Res. Communs. -2002.-290.-P. 830-838.

27. Guinn B. A., Collin J. F., Li G., Rees R. C., Mufti G. J. Optimised SEREX technique for the identification of leukaemia-associated antigens // J. Immunol. Meth. -2002.-264.P. 207-214.

28. Rodnin N. V., Thonkova I. A., Kyyamova R. G., Garifulin $O$. M., Filonenko V. V., Gout I. T. Identification of tumor-associated antigens in human thyroid pappilar carcinoma // Exp. Oncol.-2003.-19.-P. 541-547.

29. Van der Bruggen P., Traversari C., Chomez P., Lurquin $C$., De Plaen E., Van den Eynde B., Knuth A., Boon T. A gene encoding an antigen recognized by cytolytic $T$ lymphocytes on a human melanoma // Science.-1991.-254.-P. 16431647.

30. Boel P., Wildmann C., Sensi M. L, Brasseur R., Renauld J. C., Coulie P., Boon $T$, van der Bruggen P. BAGE: a new gene encoding an antigen recognized on human melanomas by cytolytic T lymphocytes // Immunity.-1995.-2.-P. 167175 .

31. Van E. B., Peeters O., De Backer O., Gaugler B., Lucas S., Boon $T$. A new family of genes coding for an antigen recognized by autologous cytolytic $\mathbf{T}$ lymphocytes on a human melanoma // J. Exp. Med.-1995.-182.-P. 689-726.

32. Tureci O., Sahin U., Schobert I., Koslowski M., Scmitt H., Schild H. J., Stenner F., Seitz G., Rammensee H. G.,
Pfreundschuh $M$. The SSX-2 gene, which is involved in the $t(X ; 18)$ translocation of 3 . synovial sarcomas, codes for the human tumor antigen HOM-MEL-40 // Cancer Res. -1996.56. -P. $4766-4772$.

33. Old $L . J$. Cancer/testis (CT) antigens - a new link between gametogenesis and cancer // Cancer Immunity.-2001.-1.P. 1.

34. Coulie P., Brichard V., Van Pel A., Wolfel T., Schneider J., Traversari C., Mattei S., DePlaen E., Lurquin,C., Szikora J., Renauld J., Boon $T$. A new gene coding for a differentiation antigen recognized by autologous cytolytic $T$ lymphocytes on HLA-A2 melanomas // J. Exp. Med. -1994.-180.-P. 3542.

35. Kawakami Y., Eliyahu S., Delgado C. H., Robbins P. F., Rivoltini L, Topalian S. L, Miki T., Rasenberg S. A. Cloning of the gene coding for a shared human melanoma antigen recognized by autologous $T$ cells infiltrating into tumor // Proc. Nat. Acad. Sci. USA.-1994.-91.-P. 3515-3519.

36. Brichard V., Van Pel A., Wolfel T., Wolfel C., De Plaen E., Lethe B., Coulie P., Boon $T$. The tyrosinase gene codes for an antigen recognized by autologous cytolytic $T$ lymphocytes on HLA-A2 melanomas // J. Exp. Med.-1993.-178.-P. 489495.

37. Kawakami Y., Eliyahu S., Delgado C. H., Robbins P. F., Sakaguchi K., Appella E., Yannelli J. R., Adema G. J., Miki $T$, Rosenberg $S$. $A$. Identification of a human melanoma antigen recognized by tumor infiltrating lymphocytes associated with in vivo tumor rejection // Proc. Nat. Acad. Sci. USA.1994.-91.-P. 6458-6462.

38. Bakker A. B., Schreurs M. W., de Boer A. J., Kawakami Y., Rosenberg S. A., Adema G. J., Figdor C. G. Melanocyte lineage-specific antigen $8 \mathrm{p} 100$ is recognized by melanomaderived tumor-infiltrating lymphocytes // J. Exp. Med.1994.-179.-P. 1005-1009.

39. Wang $R$. F., Robbins P. F, Kawakami Y., Kang $X . Q$, Rosenberg $S$. A. Identification of a gene encoding a melanoma tumor antigen recognized by HLA-A31-restricted tumor-infiltrating HLA-A3-like super motif demonstrates the overlapping peptide-lymphocytes // J. Exp. Med.-1995.-181.P. $799-804$.

40. Schmits R., Cochlovius B., Treitz G., Regitz E., Ketter $R$., Preuss $K, D$, Romeike $B$. F., Prreundschuh $M$. Analysis of the antibody repertoire of astrocytoma patients against antigens expressed by gliomas // Int. J. Cancer.-2002.-98.-P. 7377.

41. Jager D., Unkelbach M., Frei C., Bert F., Scanlan M. J., Jager E., Old $L_{n} J$., Chen Y. T., Knuth $A$. Identification of tumor-restricted antigens $\mathrm{NY}-\mathrm{BR}-1, \mathrm{SCP}-1$, and a new cancer/testis-like antigen NW-BR-3 by serological screening of a testicular library with breast cancer serum // Cancer Immunol.-2002.-28.-P. 2-5.

42. Tureci O., Sahin U., Vollmar E., Siemer S., Gottert E., Seitz G., Parkkila A. K., Shah G. N., Grubb J. H., Pfreundschuh $M$., Sly W. S. Human carbonic anhydrase XII: cDNA cloning, expression, and chromosomal localization of a carbonic anhydrase gene that is overexpressed in some renal cancers // Proc. Nat. Acad. Sci. USA.-1998.-95.-P. 7608-7613.

43. Tureci $O$., Schmitt $H$., Fadle N., Pfreundschuh $M$., Sahin $U$. Molecular definition of novel human galectin which is immunogenic in patient with Hodgkin's disease // J. Biol. Chem.-1997.-272.-P. 6416-6422.

44. Cheever M. A., Disis M. L, Bernhard H., Gralow J. R., Hand S. L., Huseby E. S., Qin H. L., Takahashi M., Chen W. 
Immunity to oncogenic proteins // Immunol. Revs.-1995.145.-P. 33-59.

45. Line A., Slucka Z., Stengrevics A., Li G., Rees R. C. Altered splicing pattern of TACCl mRNA in gastric cancer // Cancer Genet. Cytogenet.-2002.-139.-P. 78-83.

46. Rosenberg $S$. A. Progress in human tumour immunology and immunotherapy // Nature. -2001.-411.-P. 380-384.

47. Li G., Miles A., Line A., Rees $R$. C. Identification of tumour antigens by serological analysis of cDNA expression cloning // Cancer Immunol. Immunother.-2004.-53.-P. 139-143.

48. Rosenberg S. A., Lotze M. T., Muul L. M., Leitman S., Chang A. E., Ettinghausen S. E., Matory Y. L. Skibber J. M., Shiloni $E$., Vetto J. T. Observations on the systemic administration of autologous lymphokine-activated killer cells and recombinant interleukin-2 to patients with metastatic cancer // New. Engl. J.Med.-1985.-313.-P. 1485-1492.

49. Rosenberg S. A., Lotze M. T., Muul L. M., Chang A. E., Avis F. P., Leitman S., Linehan W. M., Robertson C. N., Lee $R$. $E$., Rubin J. T. A progress report on the treatment of 157 patlents with advanced cancer using lymphokine activated killer cells and interleukin-2 or high dose interleukin-2 alone // New. Engl. J. Med.-1987.-316.-P. 889-897.

50. Rosenberg S. A., Yannelli J. R., Yang J. C., Topalian S. L., Schwartzentruber D. J., Weber J. S., Parkinson D. R., Seipp C. A., Einhorn J. H., White D. E. Treatment of patients with metastatic melanoma using autologous tumor-infiltrating lymphocytes and interleukin-2 // J. Nat. Cancer Inst.-1994.86. $\rightarrow$ P. $1159-1166$.

51. Jager $E$., Jager $D$., Knuth $A$. Antigen-spesific immunotherapy and cancer vaccines // Int. J. Cancer.-2003.-106.P. $817-820$.

52. Rosenberg S. A., Yang J. C., Schwartzentruber D. J., Hwu P., Marincola F. M., Topalian S. L., Restifo N. P., Dudley M. E., Schwarz S. L, Spiess P. J., Wunderlich J. R., Parkhurst $M$. R., Kawakami Y., Seipp C. A., Einhorn J. H., White D. E. Immunologic and therapeutic evaluation of a synthetic tumor associated peptide vaccine for the treatment of patients with metastatic melanoma // Nat. Med.-1998.-4.-P. 321-327.

53. Rosenberg S. A. Gene therapy for cancer // J. Amer. Med. Assoc.-1992.-268.-P. 2416-2419.

54. Jager D., Taverna C., Zippelius A., Knuth A. Identification of tumor antigens as potential target antigens for immunotherapy by serological expression cloning // Cancer Immunol. Immunother.-2004.-53.-P. 144-147.

55. Marchand $M$., van Baren $N$., Weynants $P_{1}$, Brichard $V$., Dreno B., Tessier M. H., Rankin E., Parmiani G., Arienti F., Humblet Y., Bourlond A., Vanwijck $R$. et al. Tumor regressions observed in patients with metastatic melanoma treated with an antigenic peptide encoded by gene MAGE-3 and presented by HLA-A1 // Int. J. Cancer.-1999.-80.-P. 219-230.

56. Jager E., Gnjatic S., Nagata $Y$., Stockent $E$., Jager $D$., Karbach J., Neumann A., Rieckenberg J., Chen Y. T., Ritter G., Hoffman E., Arand M., Old $L$. J., Knuth A. Induction of primary NY-ESO-1 immunity: CD8_ T lymphocyte and antibody responses in peptide-vaccinated patients with NY-ESO-1 cancers $/ /$ Proc. Nat. Acad. Sci. USA.-2000.-97.P. $12198-12203$.

57. Jaeger E., Bernhard H., Romero P., Ringhoffer M., Arand M., Karbach J., Jlsemann C., Hagedorn M., Knuth A. Generation of cytotoxic $\mathbf{T}$ cell responses with synthetic melanoma associated peptides in vivo: implications for tumor vaccines with melanoma associated antigens // Int. J. Cancer.-1996.66. -.P. $162-169$.

58. Jager E., Ringhoffer M., Dienes H. P., Arand M., Karbach J., Jager D., Ilsemann C., Hagedorn M., Oesch $F$. , Knuth A. Granulocyte macrophage colony-stimulating factor enhances immune responses to melanoma associated peptides in vivo // Int. J. Cancer.-1996.-67.-P. 54-62.

59. Zwaveling S., Vierboom M. P., Ferreira Mota S. C., Hendriks J. A., Ooms M. E., Sutmuller R. P., Franken K. L, Nijman H. W., Ossendorp F., Van Der Burg S. H., Offringa R., Melief C. J. Antitumor efficacy of wild-type p53-specific CD4( ) T-helper cells // Cancer Res.-2002.-62.-P. 6187-6193.

60. Zeng G., Wang X., Robbins P. F., Rosenberg S. A., Wang R. $F$. CD4(_) T cell recognition of MHC class II-restricted epitopes from NY-ESO-1 presented by a prevalent HLA DP4 allele: association with NY-ESO-1 antibody production. // Proc. Nat. Acad. Sci. USA.-2001 - 98. -P. 3964-3969.

61. Chen J. L, Dunbar P. R., Gileadi U., Jager E., Gnjatic $S$. Nagata Y., Stockert E., Panicali D. L., Chen Y. T., Knuth A., Old $L$. J, Cerundolo $V$. Identification of NY-ESO-1 peptide analogues capable of improved stimulation of tumor-reactive CTL // J. Immunol.-2000.-165.-P. 948-955.

62. Thurner B., Haendle I., Roder C., Dieckmann D., Keikavoussi P., Jonuleit H., Bender A., Maczek C., Schreiner D., von den Driesch P., Brocker E. B., Steinman R. M., Enk A., Kampgen $A$., Schuler $G$. Vaccination with MAGE-3Al peptide-pulsed mature, monocyte-derived dendritic cells expands specific cytotoxic $T$ cells and induces regression of some metastases in advanced stage IV melanoma // J. Exp. Med.-1999._-190.P. $1669-1678$.

63. Herr W., Schneider J., Lohse A. W., Meyer zum Buschenfelde $K . H$. Wolfel $T$. Detection and quantification of blood-derived CD8+ $\mathrm{T}$ lymphocytes secreting tumor necrosis factor-alpha in response to HLA-A2.1-binding melanoma and viral peptide antigens // J. Immunol. Meth.-1996.-191.-P. 131-142.

64. Altman J. D., Moss P. A., Goulder P. J., Barouch D. H., McHeyzer-Williams M. G., Bell J. I., McMichael A. J., Davis $M$. $M$. Phenotypic analysis of antigen-specific $\mathrm{T}$ lymphocytes // Science -1996.-274.-P. 94-96.

65. Yee C., Greenberg P. Modulating T-cell immunity to tumours: new strategies for monitoring T-cell responses // Nat. Revs Cancer.-2002.-2.-P. 409-419.

66. Jager E., Ringhoffer M., Karbach J., Arand $M$., Oesch $F$., Knuth $A$. Inverse relationship of melanocyte differentiation antigen expression in melanoma tissues and CD8+ cytotoxic-Tcell responses: evidence for immunoselection of antigen-loss variants in vivo // Int. J. Cancer.-1996.-66.--P. 470-476.

67. Scanlan $M$., Jager $D$. Challenges to the development of antigen-specific breast cancer vaccines // Breast Cancer Res.-2001.-3.-P. 95-98.

68. Sahin U., Tureci O., Chen Y. T., Seitz G., Villena-Heinsen C., Old $L$ J., Pfreundschuh $M$. Expression of multiple cancer $/$ testis (CT) antigens in breast cancer and melanoma: basis for polyvalent CT vaccine strategies // Int. J. Cancer.-1998.78.-P. 387-389.

УДК 577.29

Надійнла до редакції 09.11.04 